\title{
KEARIFAN LOKAL ORANG SUNDA DALAM UNGKAPAN TRADISIONAL DI KAMPUNG KUTA KABUPATEN GIAMIS
}

\author{
LOCAL WISDOM IN THE EXPRESSIONS OF SUNDANESE \\ TRADITIONAL IN KUTA VILLAGE, \\ CIAMIS DISTRICT
}

\author{
Aam Masduki \\ Balai Pelestarian Nilai Budaya Bandung \\ Jl. Cinambo No. 136 Ujungberung Bandung \\ email:masduki.aam@gmail.com
}

\begin{abstract}
Abstrak
Masyarakat Sunda termasuk salah satu etnis yang sangat bangga dengan bahasa dan budayanya. Dalam Bahasa Sunda dikenal babasan dan paribasa yang merupakan ungkapan tradisional atau idiom suku Sunda. Isi dari babasan dan paribasa merupakan nilai-nilai dan kearifan lokal orang Sunda pada umumnya. Dalam babasan dan paribasa banyak sekali kearifan lokal yang terkandung didalamnya. Nilai dan kearifan lokal ini yang harus tetap dijaga dan dijadikan falsafah hidup orang Sunda. Kearifan lokal mengandung nilai, kepercayaan, dan sistem religi yang dianut masyarakat setempat.Kearifan lokal pada intinya kegiatan yang melindungi dan melestarikan alam dan lingkungan. Oleh karena itu, penting untuk mengkaji dan melestarikan kearifan lokal yang berkembang di masyarakat. Penelitian kearifan lokal dilakukan pada masyarakat adat Kuta di Kabupaten Ciamis yang berfokus pada babasan dan paribasa. Metode yang digunakan adalah metode deskriptif dalam bentuk kualitatif, dengan teknik pengumpulan data berupa observasi partisipasi/pengamatan, wawancara mendalam dengan beberapa informan dan pengunjung, serta studi pustaka. Data yang dianalisis meliputi: Makna yang terkandung dalam kearifan lokal babasan dan paribasa, terutama yang mengatur tentang manusia sebagai pribadi, hubungan manusia dengan lingkungan masyarakat, hubungan manusia dengan alam, hubungan manusia dengan Tuhan.
\end{abstract}

Kata kunci: kearifan lokal,orang sunda, dalam ungkapan tradisional, di Kampung Kuta.

\begin{abstract}
Sundanese people is one ofanethnic which is extremely proud of their language and culture. In Sundanese, it is known babasan and paribasa which is a traditional expressions or idioms of Sundanese tribe. The content of babasan and paribasais the values and local wisdom of Sundanese people in general. In babasan and paribasa, there are a lot of local knowledge contain there. Values and local wisdoms must be kept and used as a philosophy of Sundanese life. Local wisdom contain values, beliefs, and religious system which is adopted by local communities. Local wisdom on its core activities protect and preserve the natural and environment. Therefore, it is important to study and preserve the local wisdom that flourished in our society.The research of local wisdom was performed at Kuta indigenous people in Ciamis district that focuses on babasan and paribasa. The method used was descriptive method in the form of qualitative data collection techniques such as participatory observation / observation, in-depth interviews with informants and visitors, as well as literature. The data analyzed include the meaning in the local wisdom of
\end{abstract}


babasan and paribasa, especially the regulation of the human as a person, human relationships with the community, the human relationship with nature, and man's relationship with God.

Keywords: local wisdom, sundanese, traditional expressions, Kuta village.

\section{A. PENDAHULUAN}

Pengertian Kearifan lokal adalah suatu bentuk kearifan lingkungan yang ada dalam kehidupan bermasyarakat di suatu tempat atau daerah. Jadi merujuk pada lokalitas dan komunitas tertentu.

Selanjutnya Francis Wahono (2005) menjelaskan bahwa kearifan lokal adalah kepandaian dan strategi-strategi pengelolaan alam semesta dalam menjaga keseimbangan ekologis yang sudah berabad-abad teruji oleh berbagai bencana dan kendala serta keteledoran manusia. Kearifan lokal tidak hanya berhenti pada etika, tetapi sampai pada norma dan tindakan dan tingkah laku, sehingga kearifan lokal dapat menjadi seperti religi yang menjadi pedoman manusia dalam bersikap dan bertindak, baik dalam konteks kehidupan sehari-hari maupun peradaban manusia yang lebih jauh.

Adanya gaya hidup yang konsumtif dapat mengikis norma-norma kearifan lokal di masyarakat. Untuk menghindari hal tersebut, norma-norma yang sudah berlaku di suatu masyarakat yang sifatnya turun menurun dan berhubungan erat dengan kelestarian lingkungannya perlu dilestarikan,yaitu kearifan lokal.

Pengertian pengelolaan sumber daya alam dan lingkungan mengacu pada UU RI No. 23 Tahun 1997 tentang pengelolaan lingkungan hidup yang berbunyi Pengelolaan lingkungan hidup adalah upaya terpadu untuk melestarikan fungsi lingkungan hidup yang meliputi kebijaksanaan penataan, pemanfaatan, pengembangan, pemeliharaan, pemulihan, pengawasan, dan pengendalian lingkungan hidup.

Kearifan lokal merupakan pengetahuan lokal yang sudah demikian menyatu dengan sistem kepercayaan, norma dan budaya dan diekspresikan di dalam tradisi dan mitos yang dianut dalam waktu yang cukup lama ( Sunaryo dan Laxman (2003).
Kearifan lokal atau kearifan tradisional, yaitu semua bentuk keyakinan, pemahaman atau wawasan serta adat kebiasaan atau etika yang menuntun perilaku manusia dalam kehidupan di dalam komunitas ekologis.

Pengetahuan lokal ternyata bisa menjadi salah satu solusi mengatasi dampak perubahan iklim di sektor pertanian terutama dalam mengatasi krisis pangan ditingkat komunitas. Sebuah penelitian terbaru dari International Institute for Environment and Development (IIED) mengungkapkan kearifan lokal yang diajarkan turun temurun telah menuntun masyarakat tradisional yang terbelakang sekalipun mampu bertahan menghadapi perubahan iklim. Praktikpraktik tradi- disional itu disesuaikan dengan ketinggian tempat, jenis tanah, curah hujan dan sebagainya yang kesemuanya mendukung keberlanjutan lingkungan.

Ungkapan tradisional merupakan kearifan lokal yang dimiliki setiap suku bangsa dan sangat erat kaitannya dengan karakter dan nilai-nilai yang berkembang dalam suku bangsa tersebut. Beragamnya ungkapan tradisional merupakan hasil dari beragamnya kehidupan dan pengalaman setiap suku bangsa. Dalam perjalanan kehidupan setiap suku bangsa, banyak hal yang ditemukan dan dijadikan nilai-nilai dalam berkehidupan.

Dalam perkembangannya, ungkapan tradisional berkembang sesuai perkembangan zaman atau globalisasi. Adanya arus globalisasi bisa menjadi positif atau negatif, tergantung sudut pandang dan cara kita menilai dan mempertahankan kearifan lokal tersebut. Dalam ungkapan tradisional banyak sekali nilai-nilai yang baik, dan bisa dijadikan falsafah hidup. Seharusnya nilai-nilai ini tetap dipertahankan di tengah perkembangan globalisasi. Hal ini menjadi permasalahan, bagaimana kita mentrans- 
formasikan dan mengaplikasikan ungkapan tradisional dalam kehidupan sehari-hari. Agar ungkapan tradisional tetap dapat dijaga dan diinformasikan nilai-nilai kearifan lokalnya, untuk bertindak laku dalam kehidupan dan berkembang sesuai perkembangan globalisasi, sesuai dengan karakter yang kita miliki sendiri.

\section{B. METODE PENELITIAN}

Adapun metode yang dipergunakan dalam penelitian ini adalah deskriptif dalam bentuk kualitatif. Sesuai dengan jenis data yang diperlukan, yakni data kualitatif, maka teknik pengumpulan datanya pun disesuaikan dengan jenis datanya, yaitu dengan menggunakan teknik-teknik wawancara terbuka dan observasi. Wawancara dilakukan dengan tokoh adat beserta jajarannya, beberapa orang informan, yang terdiri atas para tokoh masyarakat dan aparat di desa, serta beberapa orang warga masyarakat yang memahami seluk-beluk kehidupan masyarakat setempat.

Tujuan dari penelitian ini yaitu mendekripsikan mengenai ungkapan tradisional sebagai kearifan lokal dan nilainilainya, untuk dapat berkembang sesuai perkembangan globalisasi.

Manfaat dari penulisan ini yaitu untuk memberikan informasi mengenai hubungan dan keunikan ragam babasan dan paribasa pada ungkapan tradisional di Kampung Kuta Kabupaten Ciamis.

Penulis membatasi masalah yang akan dibahas dalam hal ini, yaitu mengambil ungkapan tradisional paribasa dan babasan. Hal ini disebabkan paribasa dan babasan intensitas pemakaiannya masih sering digunakan dalam kehidupan seharihari di Kampung Kuta.

\section{HASIL DAN BAHASAN}

Kampung Kuta merupakan sebuah kampung tradisional yang masih kuat memegang aturan para leluhurnya. Kampung Kuta ini terletak di Desa Karangpaningal, Kecamatan Tambaksari Kabupaten Ciamis. Kampung adat ini dihuni masyarakat yang dilandasi kearifan lokal, dengan memegang budaya pamali, untuk menjaga keseimbangan alam dan terpeliharanya tatanan hidup bermasyarakat.

Kampung Kuta ini terletak di perbatasan Jawa Barat dan Jawa Tengah. Namun, warga kampung menggunakan bahasa Sunda sebagai bahasa sehari-hari tanpa tercampur bahasa Jawa.

Kampung yang berada di perbatasan Jawa Barat dan Jawa Tengah ini kini sudah mulai modern sejak listrik masuk ke daerahnya pada tahun 1994. Kampung Kuta pernah mendapat penghargaan dari presiden pada tahun 2002 tentang penyelamat lingkungan.

Ketua adat memimpin kampung, mengurus masyarakat, mengurus adat, dan mengatur semua yang berhubungan dengan adat. Sedangkan untuk kuncen, hanya mengantar ke hutan keramat. Untuk kuncen ini, biasanya turun temurun dari leluhurnya biasanya diturunkan kepada anak laki-laki paling besar.

Nama Kampung Kuta mengacu pada lokasi kampung di lembah curam sedalam 75 meter dan dikelilingi tebing dan perbukitan. Dalam bahasa Sunda, hal itu disebut kuta (artinya pagar tembok). Aliran listrik sudah masuk ke Kampung Kuta, sehingga memungkinkan warganya menikmati peralatan elektronik, seperti televisi, radio, dan telepon seluler. Namun, warga Kampung Kuta masih mempertahankan bentuk rumah tradisional khas Sunda.

Masyarakatnya sampai saat ini masih memegang teguh melestarikan adat leluhurnya (karuhun), amanat leluhurnya yang masih dipertahankan antara lain :

a. Rumah panggung yang harus beratap rumbia atau injuk (tidak boleh permanen). Dalam membangun rumah atau tempat tinggalnya masyarakat Kampung Kuta berpegang teguh pada pepatah atau amanah leluhurnya yaitu "Ulah rek dikubur hirup-hirup, ulah ngabangun istana jadi astana" dalam bahasa sunda yang artinya, Jangan mau dikubur hidup-hidup, 
jangan membangun istana (rumah) yang menjadi astana (kuburan). Jika kita artikan berdasarkan fenomena yang terjadi saat ini yaitu gempa bumi yang melanda Tasikmalaya beberapa waktu lalu, pepatah tersebut menuntun khususnya masyarakat kampung Kuta umumnya kepada kita semua untuk membangun rumah yang ramah akan gempa, ketaatan tersebut membuahkan ketika peristiwa gempa bumi tersebut terjadi maka tak ada satu pun bangunan atau rumah Kampung Kuta yang rusak karena spesifikasi rumah kampung adat memang merupakan rumah yang ramah akan tahan gempa, sekalipun hancur maka dampaknya tidak akan begitu parah jika menimpa penghuninya disebabkan atap rumah tersebut dibangun dengan rumbia atau injuk.

$$
\text { Masyarakat Kampung Kuta }
$$

memiliki kepercayaan dan adat yang berkaitan dengan hutan keramat. Hutan keramat dianggap oleh masyarakat sebagali. tempat yang suci atau sakral sehingga masyarakat Kampung Kuta memberlakukan berbagai aturan adat untuk melindungi hutan keramat tersebut yaitu :

- Tidak boleh mengambil hasil hutan seperti kayu, buah-buahan, hewan, dan lain sebagainya yang berada di dalam hutan keramat.

- Tidak boleh memakai pakaian serba hitam, dan pakaian seragam dinas atau seragam pemerintah.

- Tidak boleh meludah, buang sampah, buang air besar atau kecil yang dapat mengotori hutan.

- Tidak boleh berkata tidak sopan atau istilah sundanya "sompral" di hutan keramat.

- Tidak boleh memakai alas kaki seperti sandal dan sepatu.

Selain itu mereka juga mempertahankan tempat-tempat keramat (tabettabet) yaitu Leuweung Gede, Gunung Wayang, Pandan Domas, Gunung Barang, Cikasihan, Gunung Goong, dan Panyipuhan.

Melakukan Upacara Adat setiap tahunnya yaitu :
1. Nyuguh, diselenggarakan setiap bulan Mulud, yang bertujuan untuk memperingati Maulid Nabi Besar Muhammad SAW, dan sebagai ungkapan rasa syukur atas rezeki dan terhindar dari malapetaka.

2. Hajat Bumi, diselenggarakan setiap Kalimangsa kapat atau pada masa panen, tujuannya adalah ungkapan rasa syukur atas keberhasilan masyarakat Kampung Kuta dalam bercocok tanam, sekaligus memohon perlindungan untuk masa cocok tanam yang akan datang, biasnya diselenggarakan pada bulan September sampai November atau hari-hari yang dianggap baik.

3. Babarit, diselenggarakan setiap ada kejadian alam seperti lini (gempa bumi) dan kejadian alam lainnya

4. Upacara mendirikan rumah atau ngadegkeun dan mendiami rumah baru setelah mendapatkan hari baik.

Penduduk yang meninggal harus dimakamkan di luar Kampung Kuta. Hal ini disebabkan amanah dari leluhurnya untuk menjaga kesucian tanah Kampung Kuta, berkaitan dengan kesucian tanah Kampung Kuta mereka juga tidak boleh membangun tempat MCK (mandi cuci kakus) mereka memilih untuk pergi kesungai jika hendak buang air dan sebagainya.

Masyarakat memiliki Leuit atau penyimpanan gabah atau padi hasil panen. Jika terjadi rawan pangan atau paceklik, ini mengartikan bahwa Kampung Kuta memiliki jiwa sosial yang tinggi dan memiliki keinginan untuk menabung.

Memelihara dan melestarikan pohon aren sebagai sumber mata pencaharian utama masyarakat Dusun Kuta membuat gula aren.

Dilarang membuat sumur atau sumur bor, hal ini karena dapat merusak tanah dan merusak jalur air yang ada di dalam tanah, dalam mencukupi kebutuhan airnya mereka mengandalkan sumber mata air salah satunya dari mata air Ciasihan. 
Eksistensi peradaban sebuah bangsa, tentunya tidak terlepas dari masa lalu. Sebab masa kini terbentuk karena peradaban masa lalu yang sudah menjadi milik sejarah. Masa sekarang pun akan membentuk peradaban masa datang. Artinya masa lalu merupakan sebuah pelajaran yang harus dipelajari, masa sekarang harus kita jalani sebaik mungkin, dan masa depan merupakan penerapan hasil pembelajaran dari masa lalu dan masa sekarang. Tentunya masa lalu itu meninggalkan banyak kearifan lokal (local genius). Salah satunya kearifan lokal yang dimiliki oleh mayarakat Kampung Kuta. Kearifan lokal tersebut tersebar dalam adat istiadat, tradisi lisan, seni tradisi, naskahnaskah tua, dan bentuk-bentuk kebudayaan lain yang mencerminkan peradaban masa lalu. Nilai-nilai kearifan lokal kiranya dapat dimanfaatkan sebagai sumbang nilai terhadap kehidupan masa sekarang dan masa yang akan datang. Menurut pendapat Ayat Rohaedi (1986:40) mengatakan bahwa kearifan lokal (local genius) atau wujud cerlang budaya mampu bertahan, memiliki kemampuan mengakomodasi budaya-budaya baru yang menyerbu, mampu berintegrasi dengan kebudayaan baru atau budaya luar, mampu mengendalikan budaya yang ada, serta menyumbangkan nilai untuk arah kebudayaan yang akan datang.

Orang Sunda memiliki filosofi hidup silih asah, silih asih, silih asuh. filosofi ini, kalau ditafsirkan kepada teori Benjamin S. Bloom dalam bukunya Taxonomy of Education of Objectives, Cognitive Domain (1959), dapat disejajarkan dengan ranah kognitif, afektif, dan psikomotor. Sebab silih asah itu orientasi nilainya kepada peningkatan kualitas berpikir, mengasah kemampuan untuk mempertajam pikiran dengan tempaan ilmu dan pengalaman. Seperti tercermin dalam ungkapan "peso mintul mun terus diasah tangtu bakal seukeut" artinya pisau tumpul kalau terus diasah akan tajam juga; atau "cikarakak ninggang batu laun-laun jadi legok" artinya air tempias menimpa batu lama-lama batunya akan berlubang. Dengan kata lain, sebodoh-bodohnya orang kalau terus ditempa, suatu saat akan ada bekasnya dari hasil pembelajaran itu. Makna silih asih, orientasi nilainya kepada makna tingkah laku atau sikap individu yang memiliki rasa belas kasihan, tenggang rasa, simpati terhadap kehidupan sekelilingnya atau memiliki rasa sosial yang tinggi. Tercermin dalam ungkapan "ka cai kudu saleuwi ka darat kudu selebak" artinya adalah kebersamaan. "Ulah pagiri-giri calik, ulah pagiranggirang tampian" artinya jangan ada permusuhan di antara manusia. Sebab manusia itu harus "sareundeuk saigel, sabobot sapihanean, sabata sarimbagan, artinya harus memiliki jiwa kebersamaan, gotong royong atau saling menolong.

Makna silih asuh, orientasi nilainya adalah kasih sayang dalam tindakan yang nyata, sikap pragmatik seseorang. eksistensi diri, menerapkan potensi diri di masyarakat. Kepada yang lebih tua harus lebih hormat, kepada sesama harus saling menjaga, kepada yang lebih muda harus mampu mengayomi dan memberi contoh yang baik. Seperti tercermin dalam ungkapan "kudu landung kandungan kedah laer aisan" artinya hidup harus mengayomi orang lain selain mengoyomi diri sendiri. "Hirup ulah manggih tungtung, paeh ulah manggih beja" artinya selamanya dikenang dalam kebaikan dan kalau meninggal tidak meninggalkan sifat buruk.

Dalam pendidikan karakter menurut pendapat Khan (2010: 14) bahwa pendidikan karakter merupakan pendidikan yang tidak saja membimbing, dan membina setiap anak didik untuk memiliki kompetensi intelektual, kompetensi keterampilan mekanik, tetapi juga harus terfokus kepada pencapaian pembangunan dan perkembangan karakter. Jadi, manusia terdidik harus memiliki kompetensi intelektual atau silih asah, harus memiliki kompetensi keterampilan mekanik atau silih asuh, dan mampu mencapai 
pembangunan dan perkembangan karakter atau silih asih.

Kesadaran akan nilai-nilai lama untuk menjadi pegangan hidup yang akan datang sebenarnya bagian dari pembentukan karakter manusia. Sebab menurut pendapat Aziz (2011: 128) yang membentuk manusia menjadi paripurna atau insan kamil adalah agama dan lingkungan hidup yang mempengaruhi hidupnya. Agama tentunya hubungan manusia dengan penciptanya atau hubungan vertikal. Lingkungan adalah hubungan horizontal, hubungan manusia dengan manusia atau ada interaksi sosial. Manusia Sunda tentu saja mengenal hal itu, dalam satu sisi harus memiliki keterikatan kepada Yang Di Atas, dan satu sisi harus menjadi pelaku di buana panca tengah (dunia) untuk mengemban azas tri tangtu di buana (resi, rama, dan ratu), dan hubungannya harus harmonis. Keharmonisan tersebut tercermin dari pragmatisme hidup orang Sunda, yaitu karakter religius, karakter personal, etos kerja, ketertiban hukum, kepemimpinan, dan bidang pendidikan atau pengasuhan.

Karakter manusia Sunda yang diharapkan sebagai manusia yang memiliki kepribadian, memiliki sikap, memiliki karisma, dan memiliki jiwa kepedulian sosial, yaitu (1) kudu hade gogog hade tagog, yaitu memiliki penampilan yang meyakinkan, optimistik, dan karismatik; (2) nyaur kudu diukur, nyabda kudu diungang, artinya harus menjaga ucapan, tindakan atau perbuatan agar tidak menyakiti orang; (3) batok bulu eusi madu, artinya yaitu harus memiliki otak atau kecerdasan yang baik; (4) ulah bengkung bekas nyalahan, yaitu jangan salah berbuat karena hasilnya akan sia-sia atau hasilnya tidak akan baik; (5) ulah elmu ajug, artinya jangan menasihati orang tetapi dirinya sendiri butuh nasihat orang lain atau jangan mengajak orang lain berbuat baik sendirinya saja tidak baik; (6) sacangreud pageuh sagolek pangkek, artinya hidup harus memiliki prinsip; (7) ulah gindi pikir belang bayah, artinya jangan berbuat jahat, memiliki pikiran jelek pada orang, atau dengki kepada orang; (8) kudu leuleus jeujeur liat tali,yaitu hidup itu harus kuat, menanggung beban sebarat apa pun jangan menyerah.

Manusia Sunda pun dituntut memiliki katakter menjadi manusia pekerja, manusia mandiri, manusia yang memiliki etos kerja. Filosofis manusia Sunda sebagai manusia pekerja di antaranya: (1) mun teu ngoprek moal nyapek, mun teu ngakal moal ngakeul, mun teu ngarah moal ngarih, artinya kalau mau makan atau mau mempertahankan hidup maka bekerjalah; (2) tungkul ka jukut tanggah ka sadapan, artinya ialah kerjakan apa yang mesti dikerjakan, jangan terganggu oleh hal-hal lain yang mengganggu perkerjaan utama dan harus rendah hati jika telah mendapatkan kesuksesan; (3) ulah kumeok memeh dipacok, artinya jangan pernah menyerah sebelum melakukan pekerjaan, harus tetap optimis; (4) ulah kurung batokkeun, artinya manusia harus banyak bergaul agar banyak teman dan menambah pengalaman; (5) kudu bisa ka bala ka bale, artinya manusia itu harus berusaha untuk memiliki banyak pengetahuan dan keterampilan, mau bekerja apa saja asal halal, jangan memilih-milih pekerjaan yang akhirnya malah menganggur; (6) ulah muragkeun duwegan ti luhur, yaitu jangan mengerjakan sesuatu yang hasilnya malah gagal atau sia-sia; (7) ulah cacag nangkaeun, yaitu jangan mengerjakan sesuatu setangah-setengah sebab hasilnya tidak akan memuaskan, malah menjadi berantakan; (8) ulah puraga tanpa kateda, yaitu jangan mengerjakan sesuatu asal jadi saja, pada akhirnya orang yang mengerjakan kitu merasa kecewa akan hasil kerja kita; (9) ulah ngarawu ku siku, jangan menerima semua pekerjaan, serakah, semua tawaran diambil, sebab pada akhirnya akan sia-sia bahkan tidak akan berbuah; (10) hejo tihang, yaitu jangan pindah-pindah tempat kerja; (11) muru julang ngaleupaskeun peusing, jangan tergiur dengan iming-iming yang belum tentu menghasilkan, lebih baik 
tekuni yang sedang digarap tetapi hasilnya sudah menjanjikan.

Masalah keadilan harus tertanam juga dalam manusia Sunda. Leluhur Sunda sudah memberikan filosofis tentang keadilan, tujuannya agar manusia Sunda memiliki jiwa adil dan beradab, seperti yang tercermin dalam: (1) ulah cueut ka nu hideung ulah ponteng ka nu koneng, yaitu katakan salah bila salah, katakan benar kalau memang benar, jangan berpihak kepada yang salah; (2) kudu nyanghulu ka hukum, nunjang ka nagara, mupakat ka balarea, yaitu aturan harus bersumber kepada hukum, harus berbakti benar ke negara, dan kebenaran itu harus menurut orang banyak (rakyat); (3) kudu puguh bule hideungna, yaitu perkara itu harus jelas aturannya bila ingin mengambil tindakan; (4) bobot pangayon timbang taraju, artinya menimbang kesalahan harus dengan aturan yang jelas seusuai dengan kesalahan yang diperbuatnya; (5) nu lain kudu dilainkeun, nu enya kudu dienyakeun, nu ulah kudu diulahkeun; artinya harus berkata jujur jangan melarang-larang sesuatu yang tidak sesuai dengan kebenaran.

Ungkapan tradisional merupakan bagian dari khasanah folklor. Menurut Danandjaja (1984: 17) folklor perlu dipelajari sebab folklor mengungkapkan baik secara sadar maupun tidak, bagaimana folk pendukungnya itu berpikir. Selain itu folklor juga mengabadikan apa-apa yang dirasakan penting (dalam suatu masa) oleh folk pendukungnya.

Menurut Budi Rahayu Tamsyah, et al dalam $\mathrm{b}$ menjelaskan ungkapan tradisional di Sunda salahsatunya adalah Babasan dan Paribasa. Babasan adalah segala ucapan yang sudah tetap dan jelas aturan pemakaiannya. Sedangkan yang disebut dengan paribasa adalah perbandingan yang menjadi perlambang kehidupan, dibuat dalam satu runtuyan kata dan sudah tetap aturan bahasanya.

Babasan dan Paribasa merupakan ungkapan tradisional atau idiom suku Sunda. Isi dari babasan dan paribasa merupakan nilai-nilai dan kearifan lokal orang Sunda pada umumnya. Dalam babasan dan paribasa banyak sekali kearifan lokal yang terkandung di dalamnya. Kearifan lokal tersebut menjadi karakter atau falsafah orang Sunda pada umumnya. Nilai dan kearifan lokal ini yang harus tetap dijaga dan dijadikan falsafah hidup orang Sunda, sebagai bentuk wujud nilai yang terkandung dalam babasan dan paribasa.

Babasan dan paribasa mempunyai aturan yang sudah tetap atau sering disebut bahasa pakeman, sehingga babasan dan paribasa tidak bisa berubah atau pun diubah. Hal ini berdasarkan bahwa babasan dan paribasa memiliki aturan tetap.Yang dimaksudkan agar nilai-nilai dari babasan dan paribasa tetap terjaga.

Menurut Warnaen (1987:8) pandangan hidup orang Sunda dapat dikategorikan menjadi lima, yaitu: (1) pandangan hidup tentang manusia sebagai pribadi, (2) pandangan hidup tentang manusia dengan lingkungan masyarakat, (3) pandangan hidup tentang manusia dengan alam, (4) pandangan hidup tentang manusia dengan Tuhan, (5) pandangan hidup tentang manusia dalam mengejar kemajuan lahiriyah dan kepuasan batin. Kelima pandangan itu kalau dihayati dan digali tidak mungkin akan terjadi konflik, baik yang disebabkan oleh perbedaan agama, suku, bahasa, ras, warna kulit, maupun perbedaan status sosial yang lainnya.

\section{Pandangan Hidup tentang Manusia sebagai Pribadi}

Banyak ungkapan tradisional yang mengandung kearifan lokal yang isinya merupakan pandangan hidup tentang manusia sebagai pribadi. Ungkapan tradisional itu sebagai berikut:

1) Kudu hade gogog hade tagog. Makna yang terkandung dalam ungkapan tradisional tersebut yaitu, harus baik budi bahasa dan baik tingkah laku. Maksud dari ungkapan tersebut bahwa kita dalam bergaul dengan orang lain senantiasa harus 
memperlihatkan perangai dan tingkah laku yang baik. Apabila bersikap seperti itu, kita akan dengan mudah bergaul dengan orang lain. Orang lain akan menyenangi kita. Dengan siapa saja kita bergaul tidak akan menemukan masalah. Sangat tidak mungkin akan terjadi konflik, karena antara budi bahasa yang digunakan dengan tingkah laku sejalan.

2) Nyaur kudu diukur, nyabda kudu diungang (berkata harus diukur, bersabda harus ditimbang).Makna yang terkandung dalam ungkapan tersebut yaitu, segala perkataan harus dipertimbangkan sebelum diucapkan.Senantiasa kita harus mampu mengendalikan diri dalam berkata-kata. Konflik yang terjadi di Indonesia pada awalnya dari hal yang sepele. Biasanya dari ucapan yang menyakitkan. Ucapan itu keluar karena tidak diper-timbangkan terlebih dahulu. Akibatnya pihak yang lain merasa sakit hati, maka terjadilah konflik. Oleh karena itu kita harus hati-hati dengan ucapan. Kaitan dengan hal ini dalam etnis Melayu kita sudah diperingatkan dengan ungkapan lidah lebih tajam daripada pedang. Ini menunjukkan bahwa pengaruh dari ucapan kita yang menyakitkan orang lain lebih dahsat daripada sekedar pedang. Luka karena pedang dengan mudah bisa diobati, tapi luka hati karena ucapan akan sulit untuk diobatinya.

3) Batok bulu eusi madu.

Artinya, diluarnya buruk di dalamnya bagus. Misalnya tampaknya miskin dan bodoh, tetapi kaya atau pandai.

4) Ulah bengkung bekas nyalahan. Artinya, tingkah laku harus tetap baik dan benar, jangan menyimpang.

5) Ulah elmu ajug. Artinya, orang yang hanya dapat menasehati orang lain agar berbuat baik, tetapi dia sendiri berbuat

keburukan.
6) Henteu gedag bulu salambar. Artinya, tidak merasa gentar sedikitpun menghadapi musuh.

7) Sacangreud pageuh sagolek pangkek Artinya, teguh memegang pendirian, tidak pernah melanggar janji.

8) Indung suku oge moal dibejaan. Artinya, harus teguh menyimpan rahasia, apalagi rahasia negara.

9) Ulah gindi pikir belang bayah Artinya, jangan buruk hati, jangan punya pikiran buruk terhadap sesama.

10) Hambur bacot murah congcot. Artinya, banyak cakap, cerewet dan sering memarahi tetapi suka memberi makanan.

11) Kudu boga pikir rangkepan. Artinya, harus punya curiga tidak mudah percaya kepada orang lain.

\section{Pandangan Hidup Manusia dengan Lingkungan Masyarakat}

Kearifan lokal yang merupakan pandangan hidup manusia dengan lingkungan masyarakat yang akan penulis analisis sebagai berikut.

1) Kudu silih asih, silih asah, jeung silih asuh (Harus saling mengasih, saling mengasah, dan saling mengasuh). Makna yang terkandung dalam ungkapan tradisional tersebut dapat dijelaskan sebagai berikut.

Silih asih, bahwa kita hidup dengan sesama harus saling mengasihi. Kita harus menolong orang yang membutuhkan pertolongan kita. Hal ini sesuai dengan ungkapan dalam budaya Sunda kudu nulung ka nu butuh, nalang ka nu susah. Sepanjang kita mampu, apa pun bentuk pertolongan kita apabila ada orang yang membutuhkan, maka kita dengan didasari rasa cinta siap untuk menolongnya. Pertolongan yang kita berikan semata-mata karena ingin membantu, lilahitaala tidak didasari karena ingin diberi imbalan.

Silih asah, artinya saling memberi pengalaman dan pengetahuan, kekurangan seseorang ditambah oleh orang lain, kesalahan seseorang 
diperbaiki oleh sesama anggota masyarakatnya (Lubis, 2001).

Dalam konteks ini kita harus saling membelajarkan, harus saling mengisi dengan ilmu pengetahuan, sehingga kita semua menjadi manusia yang memiliki pengetahuan yang luas. Oleh karena itu kita jangan kikir dengan ilmu yang kita miliki. Ilmu yang kita miliki harus senantiasa diamalkan kepada orang lain yang membutuhkan. Berdiskusi, bertukar pikiran, dialog, dan kritik yang konstruktif pada hakikatnya merupakan implementasi dari silih asah.

Silih asuh, artinya kita harus saling menjaga, melindungi, memperhatikan, mengarahkan, dan membimbing ke arah kebaikan. Dengan demikian terjalin suasana damai, saling menghormati, dan penuh rasa kekeluargaan. Ungkapan silih asih, silih asah, dan silih asuh sekarang sudah menjadi ungkapan nasional. Ini terbukti dengan seringnya para pejabat negara mulai dari presiden sampai pejabat di bawahnya dalam berpidato atau memberikan pengarahan menyampaikan ungkapan tersebut. Hal ini bisa dimaklumi karena konsep silih asih, silih asah, silih asuh merupakan konsep tradisional yang penting dalam membina hubungan antar masyarakat, sekaligus mencegah terjadinya konflik.

2) Kawas gula jeung peueut (Seperti gula dengan nira yang matang). Gula dan peueut tidak bisa dipisahkan. Gula yang dimaksud di sini yaitu gula merah dari pohon aren. Sebelum menjadi gula yang bisa dicetak namanya peueut (gula yang masih muda). Baik gula maupun peueut sama-sama rasanya manis. Jadi, makna dari ungkapan tersebut yaitu hidup rukun, damai, saling menyayangi, tak pernah berselisih.

Gula dan peueut tidak bisa dipisahkan, karena gula berasal dari peueut. Begitupun masyarakat Indonesia idealnya harus seperti peueut dan gula. Selamanya bersatu tidak terjadi perpecahan walaupun hidup dalam keberagaman.

Tentang Manusia dengan Alam Pandangan Hidup

Kearifan masyarakat Sunda yang merupakan pandangan hidup tentang manusia dengan alam menurut (Warnaen, 1987:20), yaitu: (1) Manuk hiber ku jangjangna, (2) Jalma hirup ku akalna, (3) Jawadah tutung biritna sacaranasacarana, dan(4) Leutik ringkang gede bugang.

1) Manuk hiber ku jangjangna jalma hirup ku akalna (Burung terbang dengan sayapnya, manusia hidup dengan akalnya). Makna yang terkandung dalam ungkapan tersebut, yaitu setiap makhluk masing-masing telah diberi cara atau alat untuk melangsungkan kehidupannya. Oleh kare-na itu, jangan coba-coba kita merusak alam, karena akan merusak ekosistem yang sudah dibangun secara alami. Akibat dari ekosistem yang rusak, keseimbangan alam menjadi tidak stabil. Dari alam yang tidak stabil, akan menimbulkan bencana di mana-mana. Bencana alam yang terjadi selama ini di Indonesia, tidak menutup kemungkinan karena ekosistem alam ini sudah rusak sebagai akibat ulah manusia. Akibat dari bencana alam itu bisa saja akan menimbulkan konflik, karena kehidupan masyarakat tidak menentu dan penuh kepanikan.

2) Jawadah tutung biritna sacaranasacarana. Ungkapan ini maknanya sama dengan ungkapan ciri sabumi cara sadesa, yaitu setiap bangsa memiliki cara dan kebiasaan masingmasing. Oleh karena itu, kita harus menghargai dan menghormati cara dan kebiasaan orang lain walaupun cara dan kebiasaan itu berbeda dengan kita. Di dalam budaya Melayu ada ungkapan " $d i$ mana bumi dipijak disitu langit dijunjung". Makna yang terkandung 
dalam ungkapan tersebut yaitu apabila kita berada di suatu daerah tertentu, maka kita harus mengikuti adat istiadat atau budaya daerah tersebut. Dengan demikian, selamanya kita akan hidup damai walaupun hidup dalam keberagaman budaya, agama, suku bangsa, warna kulit, bahasa, dan lainlain.

3). Leutik ringkang gede bugang. Artinya, manusia itu meskipun kecil badannya, kalau meninggal dalam perjalanan, besar urusannya tidak seperti binatang.

\section{Pandangan Hidup tentang Manusia dengan Tuhan}

Sedikitnya ada enam ungkapan tradisional yang mengandung kearifan sebagai pandangan hidup tentang manusia dengan Tuhan (Warnaen,1987:20). Dari keenam itu hanya dua yang akan penulis analisis, yaitu mulih $\mathrm{ka}$ jati mulang $\mathrm{ka}$ asal, dan dihin pinasti anyar pinanggih.

1) Mulih ka jati mulang ka asal (Kembali ke sejati pulang ke asal). Konsep dalam ungkapan ini sama dengan apa yang terdapat dalam ajaran Islam, yaitu bahwa manusia diciptakan oleh Tuhan pada akhirnya akan kembali kepada Tuhan. Oleh karena itu, kita senantiasa me- nyiapkan diri untuk bekal nanti di alam yang kekal. Orang yang mengetahui ungkapan itu, tidak mungkin untuk membuat permusuhan di dunia ini. Justru dia akan membuat kedamaian dengan menjalin silaturahmi dengan siapa pun tanpa melihat perbedaan yang dimilikinya. Dia menganggap, bahwa secara sosial semua manusia yang ada di muka bumi ini saudara.

2) Dihin pinasti anyar pinanggih (Sejak dahulu ditentukan baru sekarang dijumpai). Maksud dari ungkapan ini yaitu, segala sesuatu yang dialami sekarang sesungguhnya sudah ada yang menentukan terlebih dahulu. Segala sesuatu yang terjadi semata- mata kehendak Tuhan. Namun, bukan berarti kita harus diam tanpa usaha. Justru ungkapan ini secara inplisit menyuruh kepada kita untuk berikhtiar.

Bukan berarti ketika konflik terjadi lalu kita menyerah dengan alasan bahwa ini sudah kehendak Tuhan, tanpa ada ikhtiar bagaimana supaya tidak terjadi konflik. Justru Tuhan menyuruh kepada kita bagaimana caranya supaya tidak terjadi konflik.

3) Nimu luang tina burang. Artinya, mendapat pengalaman atau pengetahuan pada waktu mendapat kecelakaan.

4) Buaya mangap batang liwat. Artinya, memperoleh sesuatu yang sangat diharapkan dengan tak terduga sebelumnya.

\section{Pandangan Hidup tentang Manusia dalam Mengejar Kemajuan Lahiriah dan Kepuasan Batin}

Dalam mengejar kemajuan lahiriah hendaknya kita mengacu pada ungkapan dalam budaya Sunda sebagai berikut.

1) Ulah ngukur baju sasereg awak. Artinya, jangan mempertimbangkan sesuatu hanya dari segi kepentingan pribadi.

2) Ulah pupulur memeh mantun. Artinya, jangan meminta upah sebelum bekerja.

3) Ulah kumeok memeh dipacok. Artinya, kalau menghadapi pekerjaan janganlah sebelum apa-apa sudah merasa berat.

4) Mending waleh batan leweh. Artinya, lebih baik berterus terang dari pada terus menanggung kedukaan.

5) Mending kendor ngagembol, tinimbang gancang pincang. Artinya, lebih baik lambat tetapi dengan banyak hasilnya daripada cepat dengan sedikit hasil.

6) Asa mobok manggih gorowong. Artinya, orang yang sedang mencari 
jalan, lalu mendapat pula pertolongan sehingga merasa senang.

7) Ulah puraga tamba kadenda. Artinya, dalam mengerjakan suatu pekerjaan jangan asal dikerjakan saja, tetapi harus dengan sungguh-sungguh sehingga hasilnya memuaskan.

8) Batan, kapok anggur gawok. Artinya, dari pada berhenti melakukan pekerjaan yang tidak baik, malah makin menjadi-jadi.

9) Ulah gasik nampi gancang narima. Artinya, jangan terburu-buru menerima sesuatu, hendaknya dipikirkan dulu baik buruknya.

10) Kudu bisa lolondokan. Artinya, pandai menyesuaikan diri.

11) Ulah pagiri-giri calik, pagiranggirang tampian. Makna dari ungkapan ini yaitu: Untuk mendapatkan keuntungan atau kekuasaan jangan saling berebutan tanpa mengindahkan kepentingan bersama. Kekuasaan atau jabatan yang diperoleh dengan cara-cara yang kurang baik, pada akhirnya akan berujung dengan kekacauan atau konflik. Konflik akan terjadi antara pejabat berikut pendukungnya dengan orang berikut pendukungnya yang seharusnya menempati jabatan tersebut. Selain itu, jabatan yang diperoleh dengan cara-cara kurang baik biasanya tidak memperhatikan keahlian atau profe-sionalisme orang yang akan menempati jabatan tersebut. Yang penting dia punya banyak uang dan kekuatan. Akibatnya dia tidak mampu melaksanakan tugas dengan baik. Dalam situasi seperti ini, lama-kelamaan negara Indonesia akan hancur.

Begitupun dalam mendapatkan keuntungan yang lainnya harus diperoleh dengan cara yang sesuai dengan normanorma yang berlaku, jangan merugikan orang lain. Oleh karena itu, untuk memperoleh jabatan hendaknya menempuh mekanisme atau norma-norma yang sudah disepakti bersama. Semua pihak harus konsisten atau berpegang teguh kepada norma-norma yang sudah disepakati bersama itu.

Seperti yang tertuang dalam ungkapan, Kudu paheuyeuk-heuyeuk leungeun (Harus saling berpegangan tangan). Manusia merupakan makhluk sosial. Satu sama lain saling membutuhkan. Oleh karena itu kita sebagai manusia harus tolong-menolong. Tolongmenolong merupakan awal dari terciptanya kedamaian. Budaya tolong-menolong di masyarakat perkotaan dewasa ini sudah berkurang. Hal ini karena kehidupan di perkotaan sudah bersifat individualistis. Kepedulian kepada sesama sudah berkurang. Tentu saja kalau ini tidak cepat ditanggulangi merupakan sebuah ancaman akan terjadinya perpecahan. Caranya dengan kembali memahami ungkapan tradisional yang mengandung kearifan lokal. Upaya riilnya, yaitu menciptakan suasana kekeluargaan dengan sesama. Umpamanya melalui kegiatan pengajian bersama, arisan warga, jalan-jalan bersama, dan lain-lain.

Sebaliknya dengan di kota, suasana tolong-menolong di desa sampai hari ini masih kelihatan. Upamanya apabila ada tetangga membangun rumah, keluarga yang lainnya sibuk mengirim makanan untuk sekadar mengurangi beban tetangganya yang sedang membangun itu. Begitu pun dalam mengerjakan bangunannya, banyak anggota masyarakat yang lainnya ikut membantu tanpa dibayar. Namun suasana yang penuh dengan gotong-royong itu tidak menutup kemungkinan akan hilang seperti di kota, apabila masyarakat di desa tidak memahami makna yang terkandung dalam ungkapan tradisional tersebut. Kaitannya dengan manusia dalam mengejar kepuasan batiniah, di dalam budaya Sunda ada ungkapan sebagai berikut.

1) Tiis ceuli herang mata (Sejuk pendengaran, bening penglihatan).Ungkapan ini menghendaki agar dalam kehidupan 
ini situasinya tenang, damai, tentram, dan tidak mendengar atau melihat sesuatu yang jelek atau kacau. Suasana ini hanya bisa terwujud apabila di antara masyarakat tidak ada konflik. Jadi, pesan dari ungkapan tersebut yaitu kita jangan berkonflik apa pun alasannya. Konflik itu akan membuat situasi tidak tenang, tidak damai, dan tidak tentram. Kalau situasinya seperti itu mana mungkin negara kita bisa membangun. Kita akan cape menyelesaikan konflik. Waktu akan habis digunakan untuk memulihkan keadaan. Seperti halnya ketika kita menyelesaikan konflik di Aceh.

2) Kudu bisa mihapekeun maneh (Harus dapat menitipkan diri). Sebagai manusia harus berperilaku baik. Dengan demikian banyak orang yang menyu-kainya. Di manapun dia berada walaupun berbeda agama, suku, budaya, dan lain-lain, kalau perilakunya baik, maka dia akan selamat dan akan mudah bersosialisasi. Sebagaimana telah diuraikan di muka bahwa konflik yang besar itu awalnya disebabkan oleh masalah kecil, perselisihan antarindividu. Ini semua akibat dari salah satu atau kedua-duanya tidak berperilaku baik atau tidak bisa menitipkan diri. Apabila kita ingin hidup tentram, damai, dan disayangi oleh orang lain, maka kita harus bisa menitipkan diri. Kita berada di tempat atau lingkungan baru harus pandai-pandai menitipkan diri, jangan membuat orang lain jengkel melihat perilaku kita.

Menurut Budi Rahayu Tamsyah, et al dalam buku 1.000 babasan jeung paribasa membagi babasan dan paribasa dalam tiga golongan, yaitu :

\section{Paribasa Wawaran Luang}

Paribasa wawaran luang menjelaskan mengenai pengalaman yang sudah lumrah di masyarakat, serta merupakan bahan perbandingan tingkah laku manusia. Contohnya:

1) Adat kakurung ku iga

Adat atau kebiasaan yang sulit untuk diubah. Dari paribasa ini kita bisa melihat bahwa terkadang kebiasaan manusia sulit diubah.

2) Mihapé hayam ka heulang

Makna dari ungkapan tersebut adalah menitipkan barang atau sesuatu kepada seseorang yang tidak jujur atau membahayakan. Maksud dari paribasa ini adalah untuk menjelaskan bahwa kita harus berhati-hati menitipkan sesuatu hal kepada orang yang belum kita ketahui.

\section{Paribasa Pangjurung Laku Hadé}

Paribasa pangjurung laku hadé merupakan paribasa yang isinya mendorong untuk berprilaku baik. Adapun contoh dari paribasa ini adalah :

1) Cikaracak ninggang batu laun-laun jadi legok

Apabila sesuatu dilakukan dengan sungguh-sungguh, meskipun sulit pasti bisa dilakukan. Paribasa ini mengajarkan kita sesulit apa pun suatu hal apabila kita lakukan sungguhsungguh pasti bisa dilakukan.

2) Ka hareup ngala sajeujeuh, ka tukang ngala sajeungkal

Makna dari ungkapan tersebut adalah hidup harus berhati-hati dan penuh dengan perhitungan. Dari paribasa ini mengajar-kan bahwa kita hidup jangan terlalu terburu-buru dalam bertindak, tetapi kita harus berhati-hati dan penuh perhitungan.

\section{Paribasa Panyaram Lampah Salah}

Paribasa panyaram lampah salah. menjelaskan mengenai larangan-larangan untuk tidak melakukan hal-hal yang salah atau membuat celaka. Adapun contoh dari paribasa ini adalah sebagai berikut :

1) Ulah pupulur méméh mantun Jangan meminta upah sebelum kita bekerja.

2) Ulah meungpeun carang ku ayakan 
3) Artinya jangan berpura-pura tidak tahu, membiarkan seseorang melakukan hal atau tindakan yang salah.

4) Ulah cul dogdog tinggal igel Artinya jangan meninggalkan pekerjaan tetap, untuk pekerjaan yang tidak jelas penghasilannya.

\section{Babasan dan paribasa dalam perkembangan Globalisasi}

Globalisasi adalah suatu proses dimana anta individu, antarkelompok, dan antar negara saling berinteraksi, bergantung, terkait, dan memengaruhi satu sama lain yang melintasi batas negara. Dalam banyak hal, globalisasi mempunyai banyak karakteristik yang sama dengan internasionalisasi sehingga kedua istilah ini sering dipertukarkan. Sebagian pihak sering menggunakan istilah globalisasi yang dikaitkan dengan berkurangnya peran negara atau batasbatas negara.

Globalisasi juga bisa menimbulkan dampak positif dan negatif. Positif dan negatifnya suatu hal dalam globalisasi tergantung pada setiap sudut pandang dan kebudayaan tiap-tiap negara. Hal ini bisa kita lihat dalam fenomena-fenomena globalisasi yang memengaruhi kebudayaan di negara kita. Salah satu dampak dari fenomena globalisasi itu bisa kita lihat melalui sudut pandang Babasan dan Paribasa. Contoh dampak fenomena globalisasi, yaitu :

\section{Kemajuan Teknologi}

Kemajuan teknologi merupakan fenomena globalisasi yang bisa berdampak positif ataupun negatif. Hal ini tidak bisa kita cegah, karena kemajuan tekhnologi setidaknya dibutuhkan dan akan selalu berkembang sesuai zaman. Dampak positif dari kemajuan tekhnologi, kita bisa lebih mudah untuk berkomunikasi dan berhubungan sosial antarnegara. Sementara dampak negatif dari kemajuan teknologi ini sendiri, banyaknya orang yang menyalahgunakan kemajuan teknologi untuk memeroleh informasi-informasi yang salah.

Adapun babasan dan paribasa orang Sunda yang sesuai dengan konteks kemajuan teknologi yaitu :

1) Kudu bisa miindung ka waktu, mibapa $\mathrm{ka}$ jaman. Artinya kita harus bisa mengikuti perkembangan jaman. Dengan paribasa ini setidaknya kita bisa lebih positif menggunakan tekhnologi sesuai dengan aturan dan perkembangan jaman.

2) Bengkung ngariung,bongkok ngaronjok.

Artinya sekalipun hidup susah, yang terpenting hidup berkumpul bersama keluarga. Paribasa ini sudah jarang digunakan lagi di tengah perkembangan tekhnologi pada zaman sekarang. Banyak orang Sunda yang belajar jauh ke luar negeri, akibat informasi dari teknologi. Kemajuan teknologi bisa menjadi positif apabila kita tetap berpegang teguh pada adat ketimuran kita, seperti tetap berpegang teguh pada paribasa atau babasan.Tapi kita juga harus lebih pintar memilih ungkapan dari paribasa yang sesuai dan positif terhadap perkembangan globalisasi.

Timbulnya rasa bebas dan keterbukaan dalam setiap tindakan, hal ini bisa menjadi dampak positif, contohnya kebebasan dan terbuka dalam mengemukakan pendapat. Dengan adanya kebebasan dan keter- bukaan dalam berpendapat kita bisa lebih mudah mengemukakan pendapat kita kepada khalayak umum.

Sedangkan dampak negatif dari kebebasan contohnya: budaya seks bebas, hedonisme, dan lain-lain. Hal ini sangat berlawanan dengan adat ketimuran kita. Adapun paribasa dan babasan yang sesuai dengan fenomena ini adalah:

1). Abong biwir teu diwengku

Artinya orang yang bicaranya tidak diatur atau asal bicara. Ini biasanya digunakan untuk sindiran kepada orang yang dalam berpendapatnya 
tidak bisa mengatur omongannya. Jadi meskipun akibat globalisasi kita mengenal kebebasan, bukan berarti kita bebas dalam mengemukakan apa yang kita inginkan dengan cara yang kita inginkan. Akan tetapi, harus tetap sesuai dengan aturan tata krama yang kita miliki.

2). Hade ku omong goreng ku omong Artinya segala sesuatu bisa disebut baik atau buruk disebabkan omongannya. Dari paribasa ini kita bisa melihat bahwa baik buruknya seseorang dilihat dari apa yang dikatakannya. Oleh karena itu di tengah globalisasi yang membebaskan kita untuk terbuka dalam berpendapat, kita tetap harus menjaga dan memikirkan terlebih dahulu apa yang kita bicarakan.

\section{3). Ulah ngalajur nafsu}

Artinya jangan mengikuti nafsu/keinginan sesaat. Hal ini menjelaskan bahwa ketika kita hidup jangan terlalu mengikuti nafsu, karena bisa mengakibatkan kesalahan yang fatal. Paribasa ini biasanya menjadi nasihat agar tidak terlalu mengikuti nafsu yang bisa merugikan kita dalam kehidupan sehari-hari.

Fenomena lain dari dampak globalisasi adalah adanya interaksi sosial yang mengakibatkan adanya akulturasi budaya, contohnya gaya hidup. Dampak positif dari fenomena gaya hidup yang diakibatkan globalisasi, contohnya : etos kerja, disiplin, dan menghargai waktu.

Adapun dampak negatif dari gaya hidup akibat fenomena globalisasi di antaranya berkurangnya rasa saling menghormati dan individualisme. Adapun paribasa dan babasan yang sesuai dengan fenomena ini adalah :

4). Nilas saplasna, ngadek saclekna

Artinya bahwa hidup harus proporsional atau sesuai dengan kebutuhan. Paribasa ini menjelaskan bahwa kita harus bisa disiplin melakukan hal sesuai dengan proporsinya.

5). Nete taraje nincak hambalan

Artinya harus sesuai dengan aturan dan mengikuti prosesnya. Biasanya paribasa ini digunakan untuk menasehati agar kita sabar dan mau menghargai waktu (proses) dari sesuatu hal.

6). Kudu sareundeuk saigel, sabobot sapihanean, sabata sarimbagan

Artinya harus hidup bersama-sama baik dalam duka maupun suka. Paribasa ini biasanya dipakai untuk menasihati agar kita hidup bersama-sama, jangan individualistis. Karena saling membutuhkan, maka kita harus hidup bersama-sama dalam melakukan sesuatu hal.

7). Ulah tutung atahan ari gawe teh Artinya bahwa ketika kita bekerja jangan melakukan pekerjaan setengahsetengah. Dalam paribasa ini mengajarkan bahwa kita harus bekerja secara sungguh-sungguh dalam melakukan pekerjaan. Bila mengerjakan atau melakukan sesuatu hal dengan bersunguh-sungguh, maka hasil nya pun akan baik.

Dari berbagai babasan dan paribasa, kita bisa melihat bahwa masih banyak nilai-nilai kearifan lokal yang bisa digunakan sesuai dengan perkembangan globalisasi. Derasnya arus perkembangan globalisasi merupakan hal yang tidak bisa kita cegah atau hindari. Karena perkembangan globalisasi sangat memengaruhi zaman. Hal ini bisa menjadi dampak positif ataupun negatif, bergantung bagaimana kita menghadapi perkembangan globalisasi. Apabila kita menggunakan kearifan lokal yang ada, contohnya orang Sunda menggunakan Babasan dan Paribasa dalam kehidupannya.Tentu saja hal-hal negatif dari perkembangan globalisasi bisa dicegah.

Melihat nilai-nilai babasan dan paribasa memiliki banyak kearifan lokal 
yang bisa digunakan dalam permasalahanpermasalahan globalisasi. Apabila banyak orang yang mengerti dan bisa mentransformasikan nilai-nilai tersebut, bukan tidak mungkin bahwa kita ke depannya bisa berkembang sesuai dengan perkembangan globalisasi tanpa harus menghilangkannya jati diri dan adat ketimuran yang kita miliki.

\section{PENUTUP}

Berdasarkan uraian di atas, dapat disimpulkan bahwa kearifan lokal budaya adalah suatu pengetahuan yang dikembangkan oleh para leluhur dalam menyiasati lingkungan hidup sekitar mereka, dan memperkenalkan serta meneruskan itu dari generasi ke generasi. Contohnya kearifan lokal pada ungkapan tradisional yang masih ada di zaman modern ini dan akan diwariskan secara turun-temurun sebagai budaya lokal.

Kearifan lokal menjadi penting dan bermanfaat hanya ketika masyarakat lokal yang mewarisi sistem pengetahuan itu mau menerima dan mengklaim hal itu sebagai bagian dari kehidupan mereka. Dengan cara itulah, kearifan lokal dapat disebut sebagai jiwa dari budaya lokal.

Dari pembahasan di atas tergambar dengan jelas bahwa kearifan lokal masyarakat terkodifikasi dalam adat. Adat masyarakat ini memiliki konsepkonsepnya tersendiri di setiap kelompok etnik. Dalam kearifan lokal terdapat nilainilai untuk membentuk karakter bangsa. Nilai-nilai tersebut mencakup: sistem kepemimpinan, hubungan sosial, hidup secara berkelompok, pentingnya berbagi materi dan pengalaman kepada orang lain, belajar terus dari alam, nilai-nilai gotongroyong, bagaimana menghadapi perubahan dan globalisasi, sadar akan makhluk yang mulai dari kecil, dewasa, sampai meninggal, hidup tidak boleh sombong, dan seterusnya. Kearifan lokal sesungguhnya mengandung banyak sekali keteladanan dan kebijaksanaan hidup. Pentingnya kearifan lokal dalam kebudayaan masyarakat kita secara luas adalah bagian dari upaya meningkatkan ketahanan nasional kita sebagai sebuah bangsa. Mengembangkan nilai-nilai dan budaya iptek pada dasarnya adalah melakukan tranformasi dari masyarakat berbudaya tardisional menjadi masyarakat yang berpikir kritis dan berketerampilan iptek dengan tetap menjunjung tinggi atau memelihara nilai-nilai agama, keimanan, dan ketaqwaan terhadap Tuhan Yang Maha Esa, serta nilai-nilai luhur budaya bangsa. Manusia sebagai makhluk yang berakal budi tidak henti-hentinya mengembangkan pengetahuaanya. Akibatnya dalam teknologi persenjataan, computer informasi, kedokteran, biologi, dan pangan. Kemajuan teknologi tersebut bila tidak disertai dengan nilai etika, akan merusak moral dan budaya masyarakat yangada di Indonesia.

Babasan dan paribasa merupakan salah satu hasil kebudayaan yang dimiliki orang Sunda, yang memiliki banyak kearifan lokal dan nilai-nilai baik di dalamnya. Babasan dan paribasa dapat dikategorikan dalam 3 kategori : (1) Sebagai pemberitahuan, (2) sebagai pondorong berbuat baik, dan (3) larangan dalam berbuat buruk atau salah.

Dalam perkembangan globalisasi banyak fenomena-fenomena akibat globalisasi terhadap kebudayaan kita. Fenomena globalisasi bisa menjadi positif dan negatif bergantung dari bagaiman kita menghadapinya. Dengan menggunakan pendekatan nilai-nilai babasan dan paribasa, kita bisa tetap berkembang sesuai perkembangan globalisasi, tanpa harus mengubah kebiasaan adat ketimuran kita. Jadi penggunaan nilai-nilai dari babasan dan Paribasa ini bisa kita gunakan di tengah derasnya perkembangan globalisasi.

Hendaknya kearifan budaya lokal tersebut terus ada dan dipertahankan agar tidak lenyap di era globalisasi dan modern. Serta dikembangkan lagi kearifan budaya lokal ini supaya penerus bangsa mengetahui budaya lokal negaranya sendiri. 
Penulis berharap bahwa kita tetap menjaga kearifan lokal di tengah derasnya arus globalisasi. Dengan tetap menggunakan kearifan lokal dan nilai-nilai seperti babasan dan paribasa, bisa membuat kita tetap dengan ciri pribadi. Penulis berharap kita semua bisa mentransformasikan nilai-nilai yang terkandung dalam kearifan lokal contohnya babasan dan paribasa.

\section{DAFTAR SUMBER}

\section{Buku}

Azis, H. A. 2011.

Pendidikan Karakter Berpusat pada Hati, Akhlak Mulia Pondasi Membangun Karakter Bangsa. Jakarta: Al-Mawardi.

Herlina Lubis, N. (2001).

Makalah "Kearifan Tradisional Warisan

Sejarah Sunda" pada Konferensi Internasional Budaya Sunda, Bandung.

Khan, D.Y. 2010. Pendidikan Karakter Berbasis Potensi Diri: Mendongkrak Kualitas Pendidikan. Semarang: Pelangi Publishing.

Lembaga Basa \& Sastra Sunda. 1975

Kamus Umum Basa Sunda. Bandung: Tarate.

Mustapa, R. H. Hasan. 1985. Adat Istiadat Orang Sunda. Bandung: Alumni.

Rahayu Tamsyah, Budi dkk. 1994. 1000 Babasan jeung Paribasa Sunda. Bandung : PustakaSetia.

Rosidi, Ajip. 1970. Carita Mundinglaya Di Kusumah. Bandung: Proyek Penelitian Pantun.

Rusyana, Yus dkk.1988/1989.

Pandangan Hidup Orang Sunda
(sepertiTercermin dalam
$\begin{aligned} & \text { Masyarakat Dewasa ini) Tahap III. } \\ & \text { Bandung: Depdikbud. }\end{aligned}$

Sutrisno, Sulastin. 1981.

Relevansi

Filologi:Yogyakarta Universitas Gajah Mada.

Sukatman. 2009. Butir-butir Tradisi Lisan Indonesia (Pengantar Teori dan
Pembelajarannya). Yogyakarta: LaksBang PRESSindo.

Taufiq Hidayat, Rachmat dkk.2007. Peperenian Urang Sunda. Bandung: Kiblat Buku Utama.

Warnaen, S. et al. 1987.

Pandangan Hidup Orang Sunda Seperti Tercermin dalam Tradisi Lisan dan Sastra Sunda. Jakarta: Depdikbud.

\section{Internet}

http://irwancahyadi.blogspot.com/2012/05/dam pak-positif-dan-dampak-negatif.html, diakses tanggal 2 Februari 2015 pukul 11.30 WIB.

http://ipoetmedia.blogspot.com/2010/07/dampa k-positif-globalisasi.html, diakses tanggal 6 Februari 2015 pukul 9.00 WIB.

https://imbasadi.wordpress.com/2012/11/21/ke arifan-lokal-babasan-dan-paribasa-tim-upi/, diakses tanggal 10 Februari 2015 pukul 8.00 WIB.

http://www.deptan.go.id/dpi/detailadaptasi3.ph p, diakses tanggal 12 Februari 2015 pukul 9.00 WIB.

http://budisuhardiman.blogspot.com/2010/05/re vitalisasi-kearifan-lokal-melalui.html, diakses tanggal 5 Januari 2015 pukul 10.30 WIB.

http://irwancahyadi.blogspot.com/2012/05/dam pak-positif-dan-dampak-negatif.html, diakses tanggal 6 Januari 2015 pukul 11.00 WIB.

http://ipoetmedia.blogspot.com/2010/07/dampa k-positif-globalisasi.html, diakses tanggal 9 Januari 2015 pukul 11.30 WIB.

https://imbasadi.wordpress.com/2012/11/21/ke arifan-lokal-babasan-dan-paribasa-tim-upi/, diakses tanggal 12 Januari 2015 pukul 10.10 WIB.

http://budisuhardiman.blogspot.com/2010/05/re vitalisasi-kearifan-lokal-melalui.html, diakses tanggal 15 Januari 2015 pukul 9.00 WIB.

http://lilawatyy95.blogspot.com/2013/01/penjel asan-tentang-kearifan-lokal.html, diakses tanggal 4Maret 2015 pukul 9.30 WIB.

http://naninorhandayani.blogspot.com/2011/05/ pengertian-kearifan-lokal.html, diakses tanggal 2 Maret 2015 pukul 10.30 WIB 